\title{
Water Crisis in Kabul Could Be Severe If Not Addressed
}

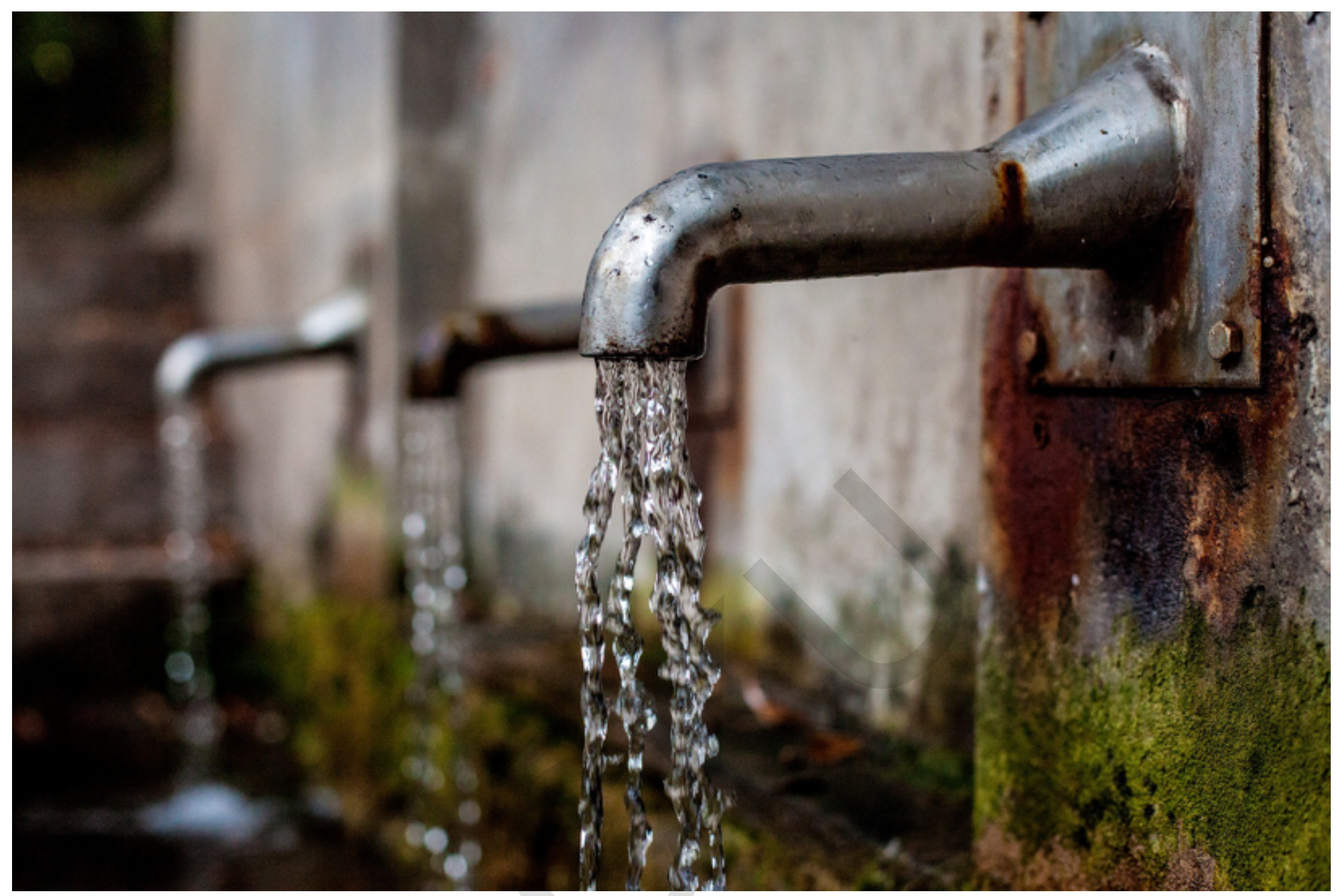

Mohsin Amin is a Former Advisor to the Afghan Energy Commission, Energy Policy Analyst and Fulbright Scholar at the School of Public Policy, Oregon State University, USA.

Elnaz Hassanpour Adeh is a Water Resources Engineering PhD candidate at Oregon State University, USA.

The Kabul River Basin, which accounts for $35 \%$ of the country's population, is the most important river basin of Afghanistan [I]. Kabul is the fifth fastest growing city in the world and among the world's most water-stressed cities [II, III]. Its population in mid-2014 was estimated at 4.5 million and is expected to increase to about 8 million by 2050. The total population of the Kabul Metropolitan Area (KMA) is projected to be 6.74 million by 2025 with 1.5 million in the new city. Water demand in the new city is projected to be $96.1 \mathrm{MCM} /$ year including industrial water use. 
With an improving standard of living and a projected population of 9 million by 2057, an estimated six-fold water consumption increase in the Kabul Basin was simulated in the groundwater-flow model described by Mack et al. (IV). The KfW study (V) estimated 123.4 million $\mathrm{m}^{3} /$ year of water demand for the Kabul city in 2015. The study estimated the groundwater potential is approximately 44 million $\mathrm{m}^{3} /$ year, capable to cover only 2 million inhabitants at a modest per capita consumption of 50 LCDP (V).

During the late 1990s, there were several years with extremely little precipitation, and in 2001, only $175 \mathrm{~mm}$ of precipitation was reported for Kabul (VI). Net groundwater recharge from direct precipitation in the Kabul Basin is generally near zero on an annual basis. Banks and Soldal (VI) reported groundwater-level decreases of 4-6 $\mathrm{m}$ in Kabul during the drought period of 1998-2002 and as much as $10 \mathrm{~m}$ in some areas.

Groundwater-level decreases of 6-7 m was reported between the 1960s and early 2000 s for some parts of the city (VII). Safi (VIII) reports that water levels in the surficial sedimentary aquifer in the city of Kabul had decreased by about $10 \mathrm{~m}$ between 1982 and 2005 because of increased water use. The water-level decreases noted by these studies in the city of Kabul, in the early to mid-200os, likely represent both the widespread effect of drought in the Kabul Basin and locally the effects of increased water use (IV).

The Urban Water Supply and Sewerage Corporation (AUWSSC) of Afghanistan estimates that $68 \%$ of Kabul residents (V) don't have access to piped water supply and just $10 \%$ of the population has access to potable water (III). Moreover, a large majority of residents are undersupplied with water, averaging about 20 liters per capita per day (LPCD), compared to a desirable level of a minimum of 80 LPCD, and a rate of over 200 LPCD for water piped to homes in developed countries (I). Kabul currently relies on groundwater from four aquifers in the Logar-Upper Kabul river basin for potable drinking water as well as for peri-urban agriculture.

Groundwater level in Kabul city between 2004 and 2012 has fallen by an 
average of 1.5 meters/year during $2008-2012$, according to the US Geological Survey (IX). The main reason is that the groundwater extraction rate is faster than the recharge rate, due to periods of below average precipitation and increased water consumption during the 2000 (IV). Additionally, an Asian Development Bank (ADB) report (I) states that groundwater levels are declining in many areas, typically from $30 \mathrm{~m}$ to 70 $\mathrm{m}$ in Kabul, due to the lack of effective regulation and excess pumping, causing many shallow wells to go dry and require deepening or replacement. Due to the absence of proper latrine facilities, unregulated waste disposal and open sewage channels, shallow aquifers are increasingly polluted, causing morbidity and child mortality and requiring drinking water to be boiled by those households sourcing their water supplies from groundwater (V). In addition, wastewater from both domestic and industrial sources is released into the Kabul river and contributes to river and shallow aquifer contamination, especially aquifers downstream of Kabul city. Hence, chemical and or bacterial pollutants are very common in untreated groundwater (I).

Surface water analysis between 1962 and 2013 in the upper Kabul basin indicates a decline in annual river flow of $38 \%$ and $25 \%$ in the Logar and the Maidan rivers respectively with a large increase in peak flow and decline in minimum flow (V). Non-piped water supply in Kabul is from private and public wells.

The Kabul city master plan estimates that there are more than 3,000 public wells that supply water to $46 \%$ of the households in non-piped water areas. In addition to public wells, $50 \%$ of households have private shallow wells of different depth. It is reported that many residents suffer from water shortages and well water contamination due to wastewater. Private wells are found throughout the city even in the areas served by piped water supply. Moreover, hand-pumped wells are managed by unregistered residents and communities and it is difficult to obtain accurate data on water distribution and consumption. While AUWSSC applies a figure of 15 $\underline{\mathrm{LCD}}$ in estimating water consumption from these wells, MRRD is trying to maintain a target of $25 \mathrm{LCD}$ and aims to increase it to 40 LCD. 
The piped water supply in Kabul City relies exclusively on groundwater resources. Three major well fields exist for AUWSSC, namely, Logar, Allaudin and Afshar. These well fields are located close to the Logar, Kabul and Pagman rivers, respectively. AUWSSC also has smaller supply resources and systems for specific areas. Over 50 wells are operated by AUWSSC. In addition, the Macrorayon system is based on 12 wells along the Kabul River. The depth of wells is generally 40-50m, although the wells of the Macrorayon system are deeper at $80-120 m$. The groundwater is pumped up by submersible pumps and stored in reservoirs (V).

All the reservoirs are ground tanks of varying sizes. Disinfection with chlorine is supposed to be done at water reservoirs, but rarely practiced due to the difficulty in procuring chlorine. From the reservoirs, the water is distributed to customers through pipelines by gravity. The water reservoirs are located on hillsides to ensure a sufficient head of water. The Logar, Allaudin and Macrorayon systems have booster pump stations to send the water through the supply lines to users (V).

\section{Governmental Structure in Afghanistan's Water Sector}

The implementing agency for water supply and sewerage in Afghanistan is the AUWSSC which was established in 2008 and administers the services for all of Afghanistan through their provincial branch offices (V). The Central Authority for Water Supply and Sewerage (CAWSS), the implementing body formerly responsible, was transferred to AUWSSC in 2009. The Kabul Municipality manages water supply and sewerage in the Macrorayon area, although it is in the AUWSSC service area. The Macrorayon Maintenance Department is responsible for managing the water supply and sewerage system there, including the sewers and sewage treatment facilities. The department, as a public maintenance company, is expected to recover its costs on the basis of the tariffs paid to it and in addition pay $10 \%$ of its revenue to the government (V). In Kabul City, only Districts 1 through 16 are presently covered by AUWSSC. The water supply for other areas is managed by the Ministry of Rural Rehabilitation and Development (MRRD). In these areas, water is supplied through private 
and community wells. Even hand pump wells located in the AUWSSC service area are under MRRD's responsibility. MRRD responsibilities for these areas will be transferred to AUWSSC, once the urban master plan is extended to cover these areas. A major task of MRRD is policy formulation, the construction of water supply facilities for unplanned areas and the management of NGO activities in this sector (V).

\section{Present Conditions Facing Piped Water Supply in Kabul}

The present service area of piped water supply is confined to the central part of Kabul City. The total number of beneficiaries is estimated roughly by AUWSSC to be 1 million, including public tap users and office workers. Domestic beneficiaries' estimation (V) is shown in Table 1 which is consistent with the AUWSSC assessment.

\begin{tabular}{|c|c|c|c|}
\hline House connections & 37,714 & $=$ & \multirow{4}{*}{$\begin{array}{l}\text { 1,030,000 } \\
\text { people }\end{array}$} \\
\hline $\begin{array}{l}\text { One domestic contract } \\
\text { serves }\end{array}$ & 12 people & 450,000 people & \\
\hline Public taps & 392 & \multirow{2}{*}{580,000 people } & \\
\hline One public tap serves & 1,500 people & & \\
\hline
\end{tabular}

Table (1): Estimation of Total Domestic Beneficiaries

Present conditions of piped water supply in Kabul declares, there are 37,714 house connections, assuming 12 people are using from one connection the total domestic users will be 450,000 (V) (in many instances, multiple families use a single connection for water). Adding this number with 392 public taps that each of them serves 1500 people, the total number of beneficiaries would be 1,030,000 which is consistent with AUWSSC study. The Macrorayon Department estimates the current service population is 100,000 , which is $13 \%$ of the total beneficiaries. The service coverage will be roughly $25 \%$ if the total number of beneficiaries served directly and indirectly by the piped water supply (V). The current population served by the piped water supply system estimated to be 
550,000 that is $13.7 \%$ of the city's population. However, the unaccounted service population is estimated to be 550,000, including public tap users. The total of $56,000 \mathrm{~m}^{3} /$ day of water is supplied through pipelines. Out of this, $38,500 \mathrm{~m}^{3} /$ day is estimated to be delivered to residents. The balance of $17,500 \mathrm{~m}^{3} /$ day is considered as physical loss. The delivered water per capita is shown in Table 2 for various householders which is considered quite low (V).

Delivered water per capita

Users living in villas and traditional dwellings

$30-40 \mathrm{LCD}$

Users living in flats

100-125 LCD

Public tap users

15-25 LCD

Table (2), delivered water for householders

\section{Challenges Faced by the Water Sector}

Water resources in Kabul city faces several challenges including a water shortage for a growing population, sharply declining groundwater levels and unpredictable policies. The present groundwater extraction is estimated to be more than $120,000 \mathrm{~m}^{3} /$ day, which exceeds the average groundwater replenishment rate of $77,500 \mathrm{~m}^{3} /$ day (V), this is unsustainable. The United Nations Economic and Social Commission for Asia and the Pacific (UNESCAP) in 2008 estimated the per capita water consumption in Afghanistan to be less than half that of other Central and West Asian countries. The World Bank projected scenarios in 2010 based on a decision-support model of the basin indicates that water use per capita will significantly increase, standard of living will improve and population will grow by 6-8 million until 2020 (IV). An increasing rate of water consumption by inhabitants as they more and more meet minimum standards, potential mining activities and an overall economic growth are expected to contribute to the increased demand for water in the Kabul Basin. Based on groundwater-flow simulations of projected increased water use in the city of Kabul, it is estimated that about $40 \%$ of existing 
wells in the surficial sedimentary aquifer may become inoperable by 2057 (X).

Policymakers and international donors have introduced "good" water governance concepts while attempting to reform Afghanistan's water sector in 2004. Consequently, the Water Sector Strategy (WSS) and the Afghan Water Law formally adopted the triangle of Integrated Water Resource Management (IWRM), River Basin Management (RBM), and participation via multi-stakeholder platforms (MSPs) in 2008 and 2009 (XII).

The introduction of the triangle framework to Afghanistan water sector is perceived as a hegemonic norm for many water governance practitioners. The adoption of the triangle demonstrates openness towards accepting global water governance norms because of its wide practice across the world. This policy goal requires to undergo a process of institutional change that is based on external models, rather than local cultural values and traditions (XII). Nonetheless, examples of institutional reforms implemented other countries have shown that theoretical models hardly produce the expected results because of complexity of the local context and due to institutional resistance (XII). Lack of adequate technical capacity in government ministries and AWUSSC exemplifies this problem. Devising the right policies at the right time is crucial for the water sector.

Furthermore, policy implementation would necessitate to build the capacity of the staff of the ministries and AWUSSC. For instance, the Ministry of Urban Development and AUWSSC have a target of reaching $100 \%$ coverage of piped water supply for urban areas by 2024. However, they have no clear plan for achieving the water supply/consumption level that the 2024 target entails, reflecting the difficulty in ensuring water resources development (V).

\section{Technical and Policy Solutions}

In addition to the existing groundwater facilities and completion of the Shatoot dam, a technical solution offers four potential water sources for 
urban water supply: the Panjshir Fan Aquifer (subsurface water and/or groundwater), the Panjsher River (surface water), and two planned storage dams, the Gulbahar Dam and the Salang Dam. The Shatoot dam and the four options above can address the water supply issues for the Kabul Metropolitan area, including the Kabul New City.

The Kabul city master plan estimates that the Shatoot dam and local groundwater will provide 87.2 and $33.2 \mathrm{MCM} /$ year respectively, as drinking water sources $(\mathrm{V})$. The concern now is the huge upfront cost of the Shatoot dam and the installation of the water treatment plant next to the dam. It will take a minimum five years to complete the construction, if no other obstacles arise. With regards the Kabul New City water supply issue, the Panjshir Fan Aquifer that takes subsurface and/or groundwater, is preferred to taking water directly from the Panjsher River due to a lower cost, dam projects generally taking a longer time to implement mainly due to high upfront costs and resettlement issues. Due to its lower cost, the Fan development project can be implemented much more quickly than the dam storage option (XI).

The Shah-Arus Dam, which is now being constructed by MEW on a tributary of the Barikab River, is planned to provide domestic water to District 17 of Kabul City. External water sources are projected to be obtained from the Panjsher Fan Aquifer, the Gulbahar Dam and the Salang Dam respectively. Therefore, the total water demand for the Kabul New City in 2025 of $96.1 \mathrm{MCM} / \mathrm{y}$ will be met by the Shomali groundwater, the Panjsher Fan Aquifer, and one of the dam (Gulbahar or Salang) reservoirs. The Shomali groundwater is expected to provide $6.8 \mathrm{MCM} / \mathrm{y}$ (This is a quick solution for the 26 Dalwa project), and the rest of the required 89.3MCM/y will be provided jointly by the Panjsher Fan Aquifer (44.6MCM/y) and the Gulbahar dam reservoir (44.7 MCM). According to JICA's study (XI), Gulbahar dam is preferred over Salang dam because of its high investment cost and lack of economic viability.

Another technical solution to the water problems in Kabul, in addition to the options outlined above, is the proposed Managed Aquifer Recharge 
(MAR) project by ADB. Similar to reservoir operation, Managed Aquifer Recharge (MAR) will increase the annual volume of underground water recharge by taking advantage of water supply availability during the rapid snowmelt and rainy seasons and store it for future usage. MAR will help stabilize or raise groundwater levels, improve the supply and quality of potable water and making Kabul urban water supplies more drought resistant and reduce the risk of land subsidence (I).

With regards to policy solutions, devising policies that promote water use efficiency at the consumer level, the harvesting of surface water and the monitoring of groundwater extraction methods at the ministry level, would be an ideal framework for the government to start with. The Afghanistan Research and Evaluation Unit (AREU) policy note (XII) suggests that policies must emphasize on identifying compromises between ideal models and local realities, as a first step, and include a wide variety of people to be trained from farmers to national ministry staff. Outputs would lead to a better compromise between "best" practices and local preferences, resulting in agreements on practical governance and management arrangements.

Secondly, the policy note recommends that water governance requires decentralization and devolution. Water users in remote areas and provinces should also be part of the scope of the policy and a practical policy should reflect the best balance in decision-making authority between government and water users.

\section{References}

2016. Asian Development Bank, "Preparing the Kabul Managed Aquifer Recharge Project”, 2016, last modified September 202016.

\section{https://drive.google.com/file/d/_oB1YNkm7THo_PTVdOaklnbDhlXok/vie} w? usp=sharing

2017. Andrew Maddocks, Robert Samuel Young and Paul Reig, "Ranking the World's Most Water-Stressed Countries in 2040", August 26, 
2015, last modified June 272017.

http://www.wri.org/blog/2015/08/ranking-world\%E2\%80\%99s-mostwater-stressed-countries-2040

- City Mayors Statistics, “The world's fastest growing cities and urban areas from 2006 to 2020", 2017, last modified Sept June 272017. http://www.citymayors.com/statistics/urban_growth1.html

2016. Thomas J. Mack, Michael P. Chornack and Mohammad R. Taher, "Groundwater-level trends and implications for sustainable water use in the Kabul Basin”, 2013, last modified September 212016.

https://drive.google.com/file/d/oB1YNkm7THo_PelJ2V2wxZXpWTHc/vi ew? usp=sharing

2016. RECS International Inc., Yachiyo Engineering Co. Ltd, "Draft Kabul City Master Plan Kabul Municipality and JICA”, 2011, last modified September 192016.

https://drive.google.com/file/d/oB1YNkm7THo_PaHFVZnlqZyooZkE/vi ew? usp=sharing

2016. David Banks, Oddmund Soldal, "Towards a policy for sustainable use of groundwater by non-governmental organizations in Afghanistan", 2002, last modified September 212016.

https://link.springer.com/article/10.1007\%2Fs10040-002-0203-y

- Georg Houben, Torge Tünnermeier, "Hydrogeology of the Kabul Basin, Groundwater geochemistry and microbiology", 2005, last modified September 212016.

https://drive.google.com/file/d/oB1YNkm7THo_PQohVcmlSbmFW NlU/view? usp=sharing

- Hassan Safi, Leendert Vijselaar, "Groundwater monitoring, evaluation of groundwater data. Danish Committee for Aid to Afghan Refugees", 2007, last modified September 222016. 
http://www.dacaar.org/Publications/6\%20Research\%20and\%20Stud ies/WASH/Groundwater\%20at\%20risk\%20in\%20afghanistanJune\%202007.pdf

2016. Thomas J. Mack, M. Amin Akbari, M. Hanif Ashoor, Michael P. Chornack, "Conceptual Model of Water Resources in the Kabul Basin, Afghanistan US Geological Survey”, 2012, Last modified September 222016.

https://drive.google.com/file/d/oB1YNkm7THo_PSXhfTGZ5 w? usp=sharing

2016. Amin Akbari, Mohammad Tahir, David W. Litke, and Michael P. Chornack, "Conceptual model of water resources in the Kabul Basin, Afghanistan. U.S. Geological Survey scientific investigations”, 2007, Last modified September 222016.

https://pubs.usgs.gov/_of/2007/1294/_pdf/ofr2007-1294web.pdf

2016. Japan International Cooperation Agency JICA, "Feasibility Study on Urgent Water Supply Resources Development for Kabul Metropolitan Area”, 2013, last modified September 222016.

https://drive.google.com/file/d/oB1YNkm7THo_PSTlmToZlOVlTR1 E/view? $\mathrm{usp}=$ sharing

- Vincent Thomas, "Good water governance models in Afghanistan: Gaps and Opportunities. Afghanistan Research and Evaluation Unit (AREU)", 2013, last modified September 202016.

https://drive.google.com/file/d/oB1YNkm7THo_POGx3TGx2Ro9RZms/v iew? usp=sharing 